\title{
PEMANFAATAN APLIKASI VIRTUAL LEARNING BERBASIS ANDROID DALAM MENINGKATKAN KUALITAS PEMBELAJARAN
}

\author{
Evan Rosiska ${ }^{1}$, Yuliadi $^{2}$, Syelfiyananda ${ }^{3}$ \\ ${ }^{1}$ Universitas Putera Batam, Sistem Informasi, Jl. S. Soeprapto, Mukakuning, Batam, \\ (0778)7001000 \\ ${ }^{2}$ Universitas Putera Batam, Akuntansi, Jl. S. Soeprapto, Mukakuning, Batam, (0778)7001000 \\ ${ }^{3}$ Sistem Informasi, Fakultas Teknik dan Komputer, Universitas Putera Batam \\ e-mail: 1evanrosiska0929@gmail.com, ${ }^{2}$ yuliadi.sikumbang@gmail.com, ${ }^{3}$ syelfia20@gmail.com
}

Informasi Artikel
Diterima Redaksi: 22 Januari 2019
Revisi Akhir: -
Diterbitkan Online: Januari 2019

Kata Kunci

Maksimal 5 kata kunci

Korespondensi

No. HP:

\begin{abstract}
Perkembangan ilmu pengetahuan dan teknologi saat ini berkembang begitu cepat, banyaknya inovasi-inovasi terbaru pada semua bidang termasuk bidang pendidikan. Perkembangan media pembelajaran berbasis teknologi informasi dan komunikasi seperti e-learning atau virtual learning yang bersifat interaktif mampu meningkatkan mutu pembelajaran karena user inteface bersifat friendly, fitur yang digunakan cukup nyaman bagi pengguna sehingga pengguna tidak bosan, selain itu teknologi bisa diakses dimana saja dan kapan saja pengguna berada, sistem pembelajaran saat ini yang masih konvensional dinilai sudah bagus dimana semua referensi yang berbentuk buku, lembar kerja siswa dan media pembelajaran lainnya harus ada, hal ini tentunya tidak semua siswa bisa memiliki semua referensi tersebut, terkadang disaat-saat tertentu pengguna lupa membawa atau harus meminjam kepada teman yang lain sehingga menjadi hambatan dalam proses pembelajaran. Akan tetapi penerapan teknologi informasi dan komunikasi diperlukan sebagai media pendukung dalam proses pembelajaran, pengguna bisa melakukan pengerjaan latihan atau mempelajari teori-teori yang berkaitan dengan proses belajar di sekolah menjadi lebih mudah dengan pemanfaatan teknologi ini. Menggunakan metode pendampingan dalam pelaksanaan kegiatan ini, yaitu mendampingi kegiatan dari awal hingga kegiatan ini berakhir, memperikan penjelasan serta manfaat yang dapat diperoleh dengan pemanfaatan aplikasi yang berbasis android dan diharapkan mampu memberikan dampak yang positif untuk pendidikan yang lebih baik.
\end{abstract}

\section{PENDAHULUAN}

Pendidikan merupakan suatu proses dalam pengembangan pengetahuan, pengembangan ketrampilan atau merubah sebuah kebiasaan yang berlangsung selama kehidupan ini. Pendidikan dapat berbentuk formal dan tidak formal, pendidikan formal didapat dari sekolah-sekolah sedangkan pendidikan tidak formal bisa diraih dari kehidupan sehari-hari, pendidikan tidak formal juga bisa diperoleh dari peristiwa yang ada disekitar kita, bahkan peran orang tua dan keluarga bisa dijadi sebagai umber pendidikan buat kita.

Jika dilihat dalam Undang-Undang Republik Indonesia Nomor 20 Tahun 2003 Tentang Sistem Pendidikan Nasional di Indonesia, Pendidikan adalah usaha sadar dan terencana untuk mewujudkan suasana belajar dan proses pembelajaran agar peserta didik secara aktif mengembangkan potensi dirinya untuk memiliki kekuatan spiritual keagamaan, pengendalian diri, kepribadian, kecerdasan, akhlak mulia, 
serta keterampilan yang diperlukan dirinya, masyarakat, bangsa dan negara.

Sementara itu perkembangan pada dunia teknologi selalu melakukan perubahan yang sangat pesat di seluruh dunia, salah satu contohnya yaitu perkembangan teknologi telepon genggam dengan menggunakan sistem operasi berbasis Android yang saat ini sudah lumrah digunakan. Jika dilihat dari grafik presentase sistem operasi perangkat mobile market share Desember 2017 - Desember 2018. Dapat dimpulkan bahwa penggunaan handphone berbasis Android meningkat. Oleh karena itu, kebutuhan akan aplikasi yang mampu dijalankan pada perangkat Android untuk berbagai bidang mengalami peningkatan. Perkembangan tersebut dapat dilihat pada gambar berikut ini:

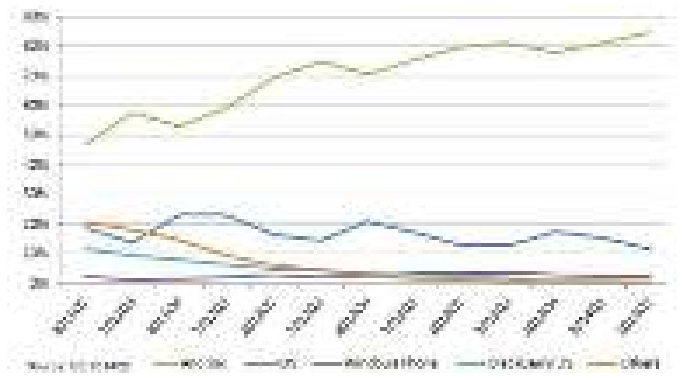

Gambar 1 Perkembangan Mobile Market Share 2017-2018

Jika dikaitkan dengan dunia pendidikan, penggunaan android dalam mendukung sistem pendidikan agar mampu menjadi lebih baik lagi adalah membuat perkembangan teknologi Informasi dan Komunikasi berbasis android seperti virtual learning. Dimana teknologi ini mampu digunakan oleh pengguna dimanapun dan kapanpun. Aplikasi yang dirancang sesuai dengan pengguna tentunya akan memberikan dampak yang baik dalam meningkatkan mutu pembelajaran.

Kalau dilihat dengan sistem pendidikan saat ini, peneliti berpendapat bahwa sistem yang digunakan sudah cukup efektif, dimana sistem pembelajaran telah menyediakan berbagai sumber referensi yang dibutuhkan. Sumber referensi bisa berbentuk buku, lembar kerja dan bentuk media pembelajaran lainnya. Akan tetapi dengan adanya sistem pembelajaran yang didukung oleh teknologi informasi dan komunikasi diharapkan mampu meningkatkan kualitas pendidikan di Indonesia, khususnya di Kota Batam.

Kegiatan pengabdian kepada masyarakat yang dilakukan di Kota Batam, Khususnya anak-anak usia produktif dalam pembelajaran dilakukan diluar jam sekolah, kegiatan ini bertujuan memberikan peningkatan ilmu pengetahuan yang dibutuhkan sesuai dengan pelajaran di sekolah. Dari pengamatan yang dilakukan di lapangan, kebanyakan peserta pengabdian hanya menggunakan buku dan lembar kerja siswa dalam menunjang proses belajar, hal ini dirasa kurang efektif untuk meningkatkan pengetahuan. Sehingga perlu dilakukan sebuah inovasi dalam meningkatkan pengetahuan tersebut. Salah satunya adalah pemanfaat teknologi virtual learning yang ada pada android. Dengan tampilan yang interaktif diharapkan mampu meningkatkan minat belajar peserta pengabdian.

Metode yang digunakan dalam kegiatan ini adalah metode pendampingan. Dimana metode ini dilakukan dengan mendampingi dari proses penginstalan aplikasi sampai penggunaan aplikasi tersebut. Selama proses berlangsung peserta diberikan kesempatan untuk berdiskusi baik berupa pertanyaan atau ketidaktahuan peserta tentang aplikasi tersebut. Dengan adanya kegiatan ini dilaksanakan, diharapkan peserta pengabdian mampu miningkatkan pengetahuan dan kemampuan belajar peserta dan mendapatkan prestasi yang baik di sekolah. 


\section{METODE}

\subsection{Waktu dan Tempat Pelaksanaan}

Kegiatan pengabdian kepada masyarakat dilaksanakan sesuai dengan kalender Pengabdian Kepada Masyarakat yang diselenggarakan oleh LPPM. Kegiatan ini dilakukan sebanyak tiga kali tatap muka, durasi waktu yang dialokasikan untuk setiap pertemuan lebih kurang dua jam. Sedangkan untuk tempat pelaksanaan kegiatan Pengabdian kepada masyarakat ini dilakukan pada masyarakat perumahan Cipta Asri Kelurahan Tembesi Kecamatan Batu Aji Kota Batam.

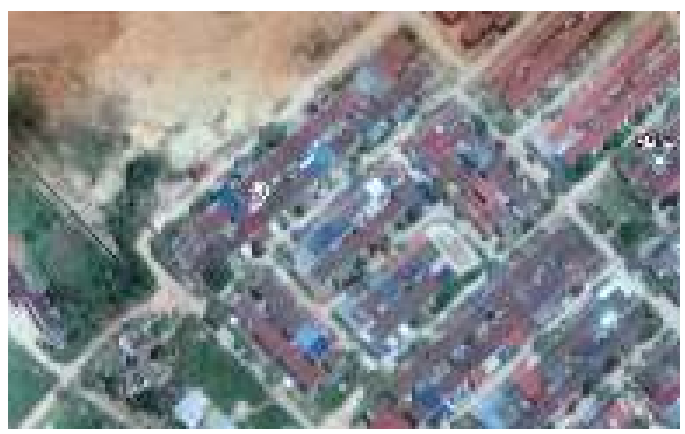

Gambar 2 Lokasi Pelaksanaan

\subsection{Metode Pelaksanaan}

Adapun teknik atau metode pelaksanaan yang digunakan agar kegiatan pengabdian kepada masyarakat ini berlangsung sesuai dengan yang diharapkan adalah:

1. Pembukaan oleh Ketua Pelaksana

Awal kegiatan yang dibuka oleh Ketua pelaksana berupa mukadimah tentang tujuan kegiatan ini dilaksanakan.

2. Memberikan materi oleh Anggota Pelakasana

Dimana untuk setiap peserta akan diberikan materi berupa tatap muka selama pertemuan dan memberikan modul pemebelajaran cara penggunaan aplikasi android, sehingga mempermudah dalam proses pemahaman untuk setiap proses instalasi aplikais tersebut. Untuk lebih jelasnya dapat dilihat pada tabel 3.1 berikut:

Tabel 1 Pemberian materi

\begin{tabular}{|l|l|l|l|}
\hline No & $\begin{array}{l}\text { Pertemuan/ } \\
\text { Tanggal }\end{array}$ & Materi & Pelaksana \\
\hline 1 & $\begin{array}{l}\text { Pertemuan } \\
\text { Pertama/ } \\
\text { Tanggal 23 } \\
\text { Desember } \\
2018\end{array}$ & $\begin{array}{l}\text { Fungsi dan } \\
\text { pengenalan } \\
\text { aplikasi }\end{array}$ & $\begin{array}{l}\text { Ketua } \\
\text { Pengabdi }\end{array}$ \\
\hline 2 & $\begin{array}{l}\text { Pertemuan } \\
\text { Kedua/ } \\
\text { Tanggal 30 } \\
\text { Desember } \\
2018\end{array}$ & $\begin{array}{l}\text { Penjelasan } \\
\text { Fitur, } \\
\text { instalasi, } \\
\text { tanya } \\
\text { jawab dan } \\
\text { evaluasi }\end{array}$ & $\begin{array}{l}\text { Anggota } \\
\text { Pengabdi }\end{array}$ \\
\hline 3 & $\begin{array}{l}\text { Pertemuan } \\
\text { Ketiga/ } \\
\text { Tanggal 6 } \\
\text { Januari } \\
2019\end{array}$ & $\begin{array}{l}\text { Penjelasan } \\
\text { Fitur, } \\
\text { instalasi, } \\
\text { tanya } \\
\text { jawab dan } \\
\text { evaluasi }\end{array}$ & Anggota \\
\hline
\end{tabular}

3. Praktek langsung oleh Ketua dan Anggota Pelaksana

Memberikan jobsheet untuk setiap tahapan pengerjaan proses instalasi aplikasi android tersebut agar mempermudah peserta yang akan mengikuti kegiatan tersebut.

4. Diskusi oleh Ketua Pelaksana

Memberikan kesempatan kepada peserta untuk bertanya jika ada materi yang masih belum dipahami oleh peserta agar peserta bisa memahami dan mendapatkan ilmu pengetahuan tambahan selama kegiatan itu berlangsung.

\subsection{Evaluasi Pelaksanaan Kegiatan}

Selama pelaksanaan kegiatan ini berlangsung, ada beberapa evaluasi yang dilakukan pada saat proses kegiatan dilaksanakan, evaluasi yang pertama dilakukan adalah menjelaskan tatacara men-download aplikasi dan menjelaskan bagaiaman penginstalannya pada handphone. Evaluasi kedua adalah memberikan kesempatan kepada peserta untuk bertanya secara langsung ketika menemukan kendala selama proses 
berlangsung, hal ini karena kegiatan ini bersifat praktek langsung.

\subsection{Keberlanjutan Kegiatan}

Untuk keberlajutan setelah kegiatan pengabdian kepada masyarakat ini yang dilakukan bersamaan dengan tim pengabdian, untuk setiap proses penggunaan aplikasi tersebut dilakukan pengulangan proses penggunaan aplikasi android tersebut dari proses download aplikasi sampai penerapakan aplikasi dan membantu mengembangkan kemampuannya dalam proses pengelolaan aplikasi yang dialakukan.

\section{HASIL DAN PEMBAHASAN}

Adapun hasil dari kegiatan pengabdian kepada masyarakat ini dalam pemanfaatan aplikasi virtual learning berbasis android mampu memberikan dampak kepada peserta dalam tingkatan ilmu dan pengetahuan bagi peserta pengabdian. Aplikasi android yang digunakan dalam meningkatkan pengetahuan adalah Sejarah Indonesia Kelas 11 Kurikulum 2013 atau aplikasi Android Buku Sekolah Elektronik (BSE) yang dikembangkan oleh Linear Studio Apps.

Untuk tempat pelaksanaan dilakukan pada salah satu rumah warga yang bersedia untuk dijadikan sebagai tempat pelaksanaan kegiatan. Hal ini menunjukkan bahwa dukungan masyarakat sangat tinggi dalam meningkatkan mutu pembelajaran.

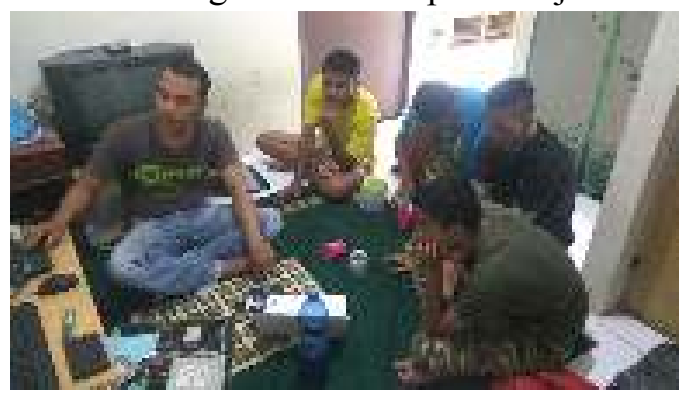

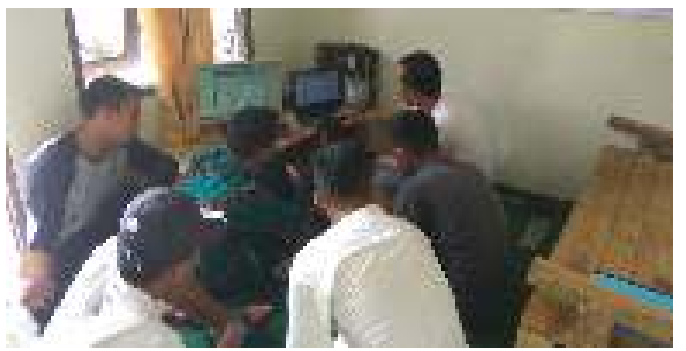

Gambar 3. Suasana Pelaksanaan Kegiatan

Kegiatan pertama dilakukan pada tanggal 23 Desember 2018 dengan memberi gambaran tentang aplikasi yang akan digunakan. Kemudian dilanjut pada pertemuan kedua dan ketiga pada tanggal 30 Desember 2018 dan 6 Januari 2019.

Aplikasi ini menampilkan fitur yang mudah untuk dipahami dan digunakan. Aplikasi ini merupakan buku gratis yang dapat disebarluaskan ke masyarakat dan dikelola oleh Kemeterian Pendidikan dan Kebudayaan. Buku ini dilengkapi materimateri yang digunakan pada SMA kelas 11 dan sesuai dengan kurikulum 2013, dimana dilengkapi beberapa materi sebanyak 4 bab, dan dilengkapi dengan kamus kata atau glosarium yang terdapat pada buku tersebut dan sumber-sumber referensi yang digunakan. Berikut ini dapat dilihat beberapa contoh penggunaan fitur pada aplikasi Virtual Learning:

1. Halaman Sampul

Pada saat aplikasi dijalankan, maka akan muncul tampilan halaman sampul dari materi Sejarah Indonesia.

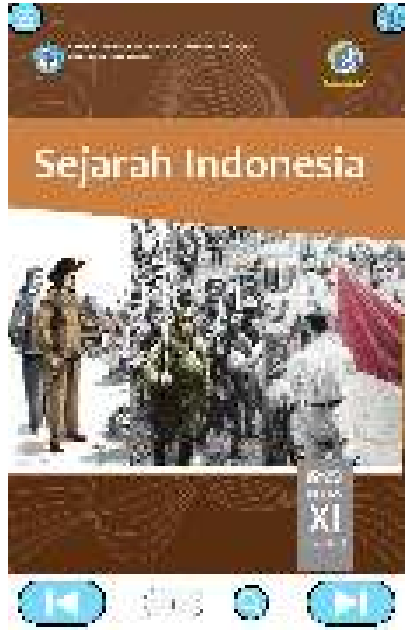

Virtual Learning Berbasis Android 
Gambar 4. Halaman Sampul

2. Daftar isi

Aplikasi ini dilengkapi dengan daftar isi yang digunakan untuk mempermudah pengguna dalam mencari sub materi yang ingin dipelajari. Klik tombol next untuk melihat daftar isi halaman berikutnya.

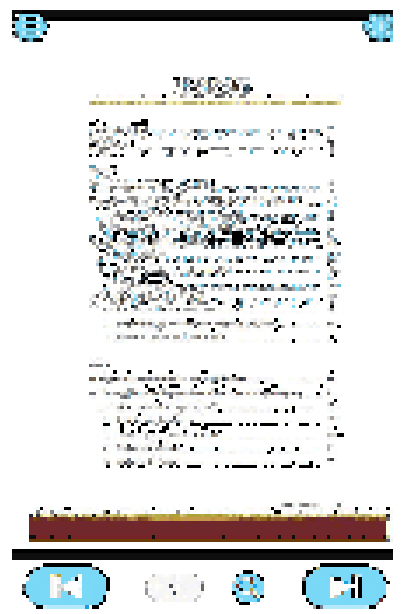

Gambar 5. Daftar Isi

3. Materi Bab 1

Berikut adalah tampilan materi untuk bab 1 tentang antara kolonialisme dan impereialisme pada aplikasi virtual learning Sejarah Indonesia.

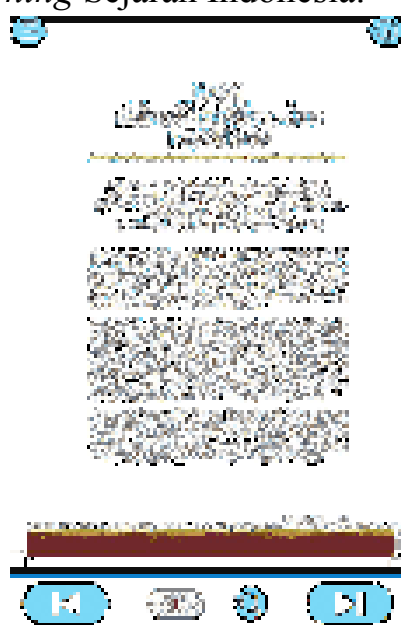

Gambar 6. Materi Bab 1

4. Materi Bab 2

Berikut adalah tampilan materi untuk bab 2 tentang perang melawan kolonialisme dan imperialisme pada aplikasi virtual learning Sejarah Indonesia.

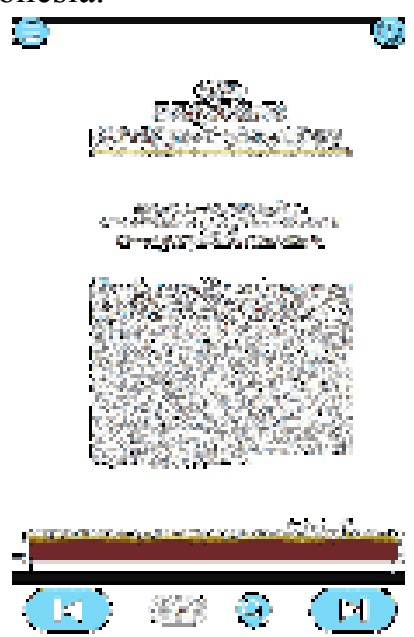

Gambar 7. Materi Bab 2

\section{Materi Bab 3}

Berikut adalah tampilan materi untuk bab 3 tentang dampak perkembangan kolonialisme dan imperialisme pada aplikasi virtual learning Sejarah Indonesia.

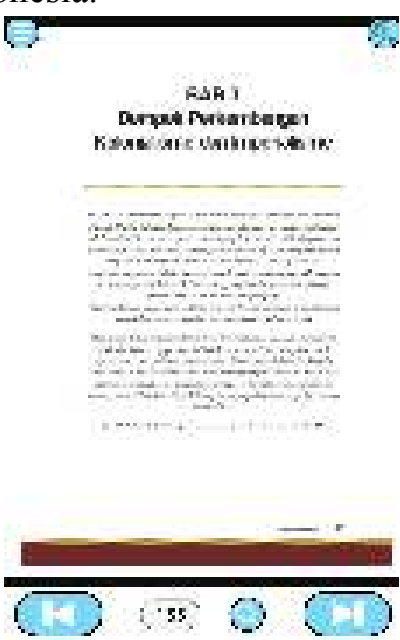

Gambar 8. Materi Bab 3

6. Materi Bab 4

Berikut adalah tampilan materi untuk bab 4 tentang sumpah pemuda dan jati diri keindonesiaan pada aplikasi virtual learning Sejarah Indonesia. 


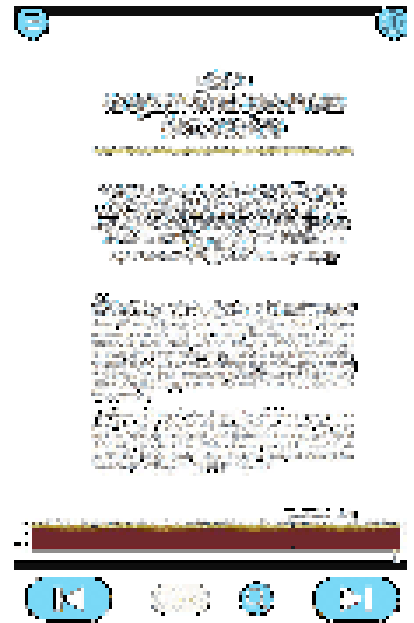

Gambar 9. Materi Bab 4

7. Daftar Istilah

Daftar istilah merupakan penjelasan tentang istilah-istilah yang digunakan dalam aplikasi ini.

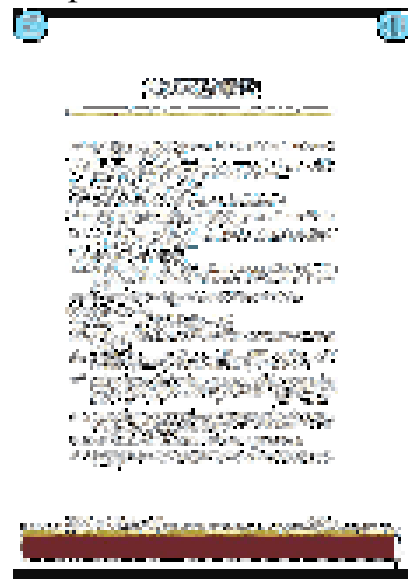

Gambar 10. Daftar Istilah

8. Daftar Pustaka

Merupakan daftar referensi yang digunakan dalam mendukung buku ini.

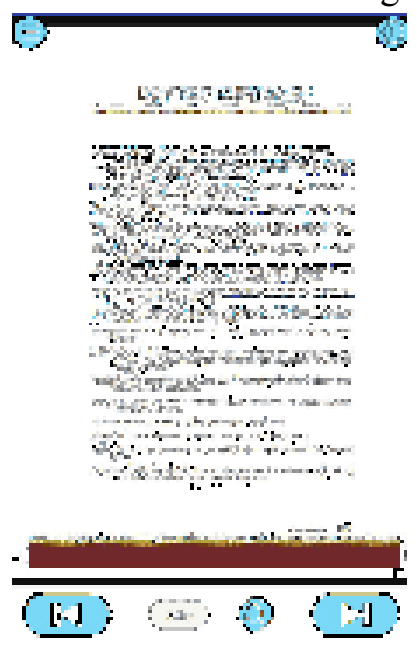

Evan Rosiska
Gambar 11. Daftar Pustaka

\section{KESIMPULAN}

Berdasarkan hasil kegiatan pengabdian kepada masyarakat yang dilakukan pada masyarakat perumahan Cipta Asri Kelurahan Tembesi Kecamatan Batu Aji Kota Batam, maka dapat diambil beberapa kesimpulan yaitu:

1. Pemanfaatan aplikasi android dalam membantu proses pembelajaran diluar sekolah mampu memberikan dampak efektifitas yang baik untuk menunjang penambahan ilmu dan pengetahuan.

2. Dengan adanya aplikasi berbasis android ini, proses pembelajaran bisa dilakukan dimana saja dan kapan saja.

3. Besarnya dampak yang diberikan dalam pemanfaatan aplikasi ini dapat diukur dari pemahaman saat dilakukan evaluasi terhadap peserta, dimana tingkat pemahaman sebelum dilakukan kegiatan ini adalah skitar $30 \%$, dan setelah dilakukan kegiatan ini, tingkat pemahaman meningkat menjadi $70 \%$.

\section{SARAN}

Saran-saran untuk untuk pengabdian lebih lanjut untuk menutup kekurangan pengabdian. Tidak memuat saran-saran diluar untuk pengabdian lanjut.

\section{UCAPAN TERIMA KASIH}

Kepada semua pihak yang telah mendukung kegiatan ini dari awal pelaksanaa hingga kegiatan ini berjalan dengan baik. Khususnya peserta pengabdian yang telah bersedia meluangkan waktu untuk mengikuti kegiatan ini. Diharapkan dengan adanya kegiatan ini mampu meningkatkan ilmu dan pengetahuan yang dapat diterapkan di bang sekolah. Meskipun target capaian belum dapat dikatakan sempurna, saran dan masukkan sangat kami perlukan agar kegiatan berikutnya bisa lebih baik lagi.

Virtual Learning Berbasis Android 
DAFTAR PUSTAKA

[1] LPPM. 2016. Panduan Pengabdian kepada Masyarakat Universitas Putera Batam. LPPM UPB Batam.

[2] Undang-Undang Nomor 20 Tahun 2003 Tentang Sistem Pendidikan Nasional.

[3] Kementerian Pendidikan dan Kebudayaan. 2014. Sejarah Indonesia SMA/MA/SMK/ Kelas XI Semester 1. Pusat Kurikulum dan Perbukuan, Balitbang, Kemdikbud. 